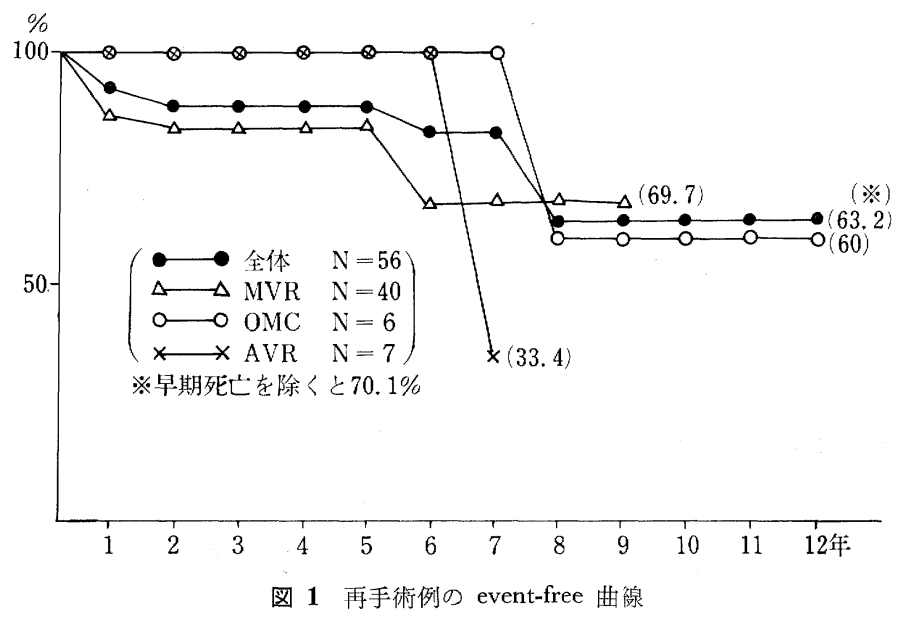

場合. 早期死亡 5 例を除くと遠隔期合併症としては人工 弁置換術後の合併症が 3 例 (血栓弁, paravalvular leakage, cloth wear) であり, 再 OMC 後 7 年 10 力月目 に他施設で MVR をらけた 1 例の計 4 例であった.

\section{考察および結語}

弁膜症 690 例中 54 例 58 回の再手術を行い死亡率 $8.6 \%, 10$ 年合併症 free 率 $63.2 \%$ (早期死亡を除く と $70.1 \%$ )であった. 手術では全例心臓全周の癒着は く離を行ったが，より良い手術視野, 確実な心筇保護, 確実な空気抜きのため注必須の条件である。しかしそ のための合併症は少なく, 手術時間が 2 時間, 体外循環

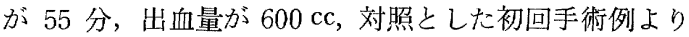
多かったに過ぎない，死亡例の大部分は手術の至適時期 を失した全身状態悪化例であったことを考慮すれば，心 機能的に再手術が必要な例ではより早期に手術を行らこ とが望ましく，いつ再手術を行うべきかの決定が現在の 最大の問題点であると考觉る。

文 献 1) Stephen Londe, M. D., and W. L. Sugg, M. D. The Challenge of Reoperation in Cardiav Surgery Ann. Thorac. Surg. 17(2):157, 1974. 2) Repeat open intracardiac operation Analysis of fifty operations. Terence, A. H., English, M. B., B. Sc., F. R. C. S., and Benjamin, B., Milstein, M. B., F. R. C. S. G. Thorac. Cardiovasc. Surg. 76(1) : 56, 1978.

\title{
A II-21 弁膜症再手術の適応と手技の工夫
}

\section{札幙医科大学 胸部外科 \\ 佐々木 孝 数井 暉久 山本 直樹 井上 紀雄 渡辺祝安星野豊 小松作蔵}

\section{目的}

教室における心臓弁膜症の外科治療は 1983 年 5 月 15 日現在 1500 例を越え, 長期生存例の增加に 伴い再 手術を要する症例も増加している。現在まで 169 例の 再手術を経験しているが，今回これら症例の経験から再 手術の適応沶よび手術手技に関し検討を加えたので報告
する.

\section{対象亡方法}

対象は I 群：自己弁温存手術後の再悪化例に対する再 手術 98 例. II 群: 弁置換後, 代用弁に起因する合併症に 対する再手術 71 例である. 再手術の適応は，I 群では 自覚症状の增悪あるいは心不全の再発 80 例, 脳塞栓発 
症あるいは左房内血栓の証明 13 例, 術後急性心不全 5 例, 感染性心内膜炎を 2 例飞認め, 外来定期検診での心 䧴音增強およびUCG チェックによる再狭窄所見を認め

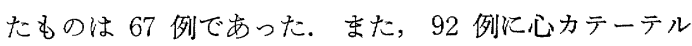
等精査にて血行動態の悪化，心機能の低下を認めた．II 群では, 縫合不全 24 例（5ち 10 例に感染性心内膜炎 -PVE一を合併), 血栓弁による機能不全 11 例, 代用 弁の機構破綻 13 例, 塞栓症頻発 5 例, 選択的再弁置換 18 例であった。手術手技は，I群では Re-MS 汶対す る Re-OMC 36 例, MVR 48 例, Re-MR に対し M VR 9 例, Re-AR に対し AVR 5 例であり, II群では Re-MVR 29 例, Re-AVR 29 例, 多弁再置換 3 例, 血栓除去術 3 例, 弁周囲逆流修復術 7 例であった。

再手術時の到達法は, 僧帽弁に対して第 1 期手術を左 開胸， 2 期手術を右開胸，それ以後は胸骨縦切開で行い 再手術時の癒着剥離を最小限汇するよう配慮したことも あったが，現在は専ら胸骨縦切開で行っている．緊急手 術や患者が poor risk の場合はまず大腿動静脈部分体外 循環を行い，これにより存在する肺水腫などは著しく軽 減される。 また, 心内圧を減少し心筋面の剥離を容易に すること, 再胸骨綐切開時の心室壁損傷等, 不慮の出血 に対処することなどにる有用である。

再弁置換比打る置換弁の摘出では, 決してメスを深 く刺入せずに解剖学的に安全な部位から切離を開始し， 金属輪沿沿って縫着輪を生体側飞残すよう飞切離し, 置 換弁切離後残存縫着輪の処置を行らょらに工夫している. 再置換漈しての縫合法は縫着部位が脆弱な場合には, 大動脈弁位では大動脈壁外に teflon felt をお京固定する 方法, 僧帽弁位では teflon pleget または teflon spaghetti を用いて固定を強固にしている.しかしながら PVE に起因する Re-AVR にて術後再逆流を認めた症 例を 2 例経験して括り, その 1 例には, 大動脈弁の translocation を行っている. すなわち, 弁輪部全周にわた る膿場のため弁輪部への人工弁縫着は不能であるため, valved conduit を使用乙上行大動脈洋着, 左右冠動

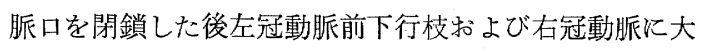
伏在静脈を用い A-C バイパスを行った.

\section{結果}

I 群では, Re-OMC; 早期死 5 例 (13.9), MVR; 早期死 4 例 $(7.0 \%), A V R$; 早期死 2 例 (40\%) であり, II群では早期死が Re-MVR：12 例 (41.4\%), Re-AV $\mathrm{R} ; 9$ 例 $(31.0 \%)$. 多弁再置換 : 1 例 $(33.3 \%)$, 血栓 除去術：0, 弁周囲逆流修復術 1 例（14.3\%）であった.
表 1 手術成 績

I 群 : 自己弁温存手術後再手術

\begin{tabular}{crrrr}
\hline 手 術手 技 & 症例 & 早期死 & 晚期死 & 生存率 \\
\hline 直視下僧帽弁 & 36 & $5(13.9 \%)$ & 1 & $83.3 \%$ \\
$\begin{array}{c}\text { 再連切開術 } \\
\text { 僧 帽 弁 置 換 術 }\end{array}$ & 57 & $4(7.0 \%)$ & 1 & $91.2 \%$ \\
大動脈 弁 置 換 術 & 5 & $2(40 \%)$ & 1 & $40 \%$ \\
\hline 計 & 98 & $11(11.2 \%)$ & 3 & $85.7 \%$ \\
\hline (1980. 1. 1 以降) & 24 & $2(8.3 \%)$ & 1 & $87.5 \%$ \\
\hline
\end{tabular}

II 群 : 弁置換術後再手術

\begin{tabular}{crrrr}
\hline 手 術手 技 & 症例 & \multicolumn{1}{c}{ 早期死 } & 晚期死 & 生存率 \\
\hline 僧帽弁 再 置 換術 & 29 & $12(41.4 \%)$ & 7 & $34.5 \%$ \\
大動脈弁再置換術 & 29 & $9(31.0 \%)$ & 4 & $55.2 \%$ \\
多 弁 再. 置 換 術 & 3 & $1(33.3 \%)$ & 0 & $66.7 \%$ \\
血 栓 除 去 術 & 3 & 0 & 2 & $33.3 \%$ \\
弁周囲逆流修復術 & 7 & $1(14.3 \%)$ & 1 & $71.4 \%$ \\
\hline 計 & 71 & $23(32.4 \%)$ & 14 & $47.9 \%$ \\
\hline (1980. 1. 1 以降) & 13 & 0 & 1 & $92.3 \%$ \\
\hline
\end{tabular}

I 群で早期死 11 例 (11.2\%), II 群で 23 例 (32.4\%) と初回手術に比し不良であるが, 最近 3 年間では I 群 24 例中早期死 2 例 $(8.3 \%)$, II 群 13 例中早期死はな く成績の向上を見ている（表 1 ）。大動脈弁の translocation を施行した症例は，術後の精査にてグラフトの 良好な開存を認めており, 術後 4 力月の現在炎症の再発 も認めず健在でめる.

\section{考案}

心臓弁膜症に対する手術は現時点でも根治的とは言い 難く，長期生存例の増加に伴い再手術例も増加している. 再手術の適応は I 群では徐々に症状が悪化し心不全に至 る症例が多く, 待期的に心カテーテル等にて適応を決定 したが，術後早期の升修復の破綻による急性心不全に対 しては緊急手術の適応となった，また，超音波検査で左 房内血楏が証明された症例は手術適応としている.

II群にお汀る弁周团逆流飞対して, 大動脈弁では Sellers II以上の逆流があれば積極的に再手術を，僧帽弁 では逆流発生の確証が得られたなら可及的早期炕再手術 を行っている. 置換升機能不全例では血栓弁であれ，弁 機構破綻であれ確証が得られたら直らに手術適応とすべ きである. PVE の併発に対しては積極的に早期手術を 施行する方針をとっているが，大動脈弁輪部膿瘍のため 再弁置換が不能な症例には translocation が有用な 方法 
と思われる、しかしながら本法はすべての冠血流量がグ ラフトに依存しており, 将来に打活るグラフト閉塞の可 能性, また弁輪部膿瘍廓清後, 同部の拡大, 破裂等の危 険性も有しており慎重な follow up が必要である.

弁膜症再手術には種々の問題点を含んでいるが，心筋
保護の確立，拍動流体外循環，術後早期よりの IABP 使 用等により手術成績も向上しておら, 手術効果もをた大 であることから積極的姿勢で対処することが肝要と考克 る.

\title{
A II-22 弁膜症再手術の死亡例扣よび術後合併症よりみた 再手術の適応
}

\author{
済生会宇都宮病院 心蔵外科, 産業医科大学 第 2 外科*

内藤 千秋 木曾 一誠 林 郁夫 石倉 義弥*

近年，開心術の手術成績はめざましい向上をみている が，再開心術の手術成績は必ずしも良好とは言い難い。 この原因として，再手術時の心機能や，癒着による手術 操作の困難性, 手術侵襲による術後合併症の関与などが 考学られる.われわれは, 升膜症再手術の死亡例の死因 拉よび術中術後の合併症を検討し，弁膜再手術の手術適 応と術中術後の留意点を考察した。

\section{対象}

1973 年から 1982 年の 10 年間に 当院における弁膜 症手術例数は 206 例で, このらち 15 例に 16 回の再 手術を施行し，20 升に手術操作を加壳た。年令は 18 才から 46 才 (平均 34 才), 男性 9 例, 女性 6 例であ った。

\section{結果}

弁膜症再手術 20 弁の内訳と再手術術式拈よび死亡数 は（表 1)，大動脈升疾患 7 弁で死亡 3 例，僧帽弁疾患 10 弁で死亡 1 例, 三尖弁疾患 3 弁で死亡例は認めなか

$$
\text { 表 } 2 \text { を め }
$$

1）弁膜症再手術死亡例 4 例中 3 例は大動脈升疾患（全例 paravalvular leak で，再手術前飞心不全が著明であっ t.

2）再僧帽弁置換術死亡例の 死因は 肝督不全。（三尖弁疾患 は 3 例之手生存.)

3）弁膜症再手術生存例では野篤な合併症を認女なかった。

4) 当院では，大動脈弁再手術伩しては，再々手術回避の 意味を含め AVR を，僧帽弁・三尖升疾患墽しては 可能なかぎり自己弁の温存涿務める方針である.
った．各疾患の再手術の原因と死亡例の関係は，大動脈 弁疾患での死亡例 3 例はすべて paravalvular leak に上 る再弁置換症例で, 僧帽弁疾患での死亡例 1 例は, 直視 下交連切開術後の再狭窄による僧帽弁置換術例であった。 死亡 4 例とも再手術時に弁置換術を施行した症例で, 再 手術時弁形成術を施行した症例には死亡例はなかった。 これら 4 例の死因は, 大動脈弁疾患では LOS による術 中死亡 2 例, 心室性不整脈 1 例で, 僧帽升疾患では術後 原因不明の肝腎不全が 1 例であった。 また, 生存例では 重篤な合併症は認めず, 術後経過も良好であった。

術中合併症としては, わ机わ机は全例胸骨正中切開で 心に到達しているが，中等度から強度の癒着があり, 癒 着剥離中に右房損稘 3 回, 右開胸 4 回, 左開胸 1 回を認 めたが, 死亡の直接原因とはならなかった。再手術術中 出血量は $832 \pm 792 \mathrm{~m} l$ (初回手術例 $471 \pm 230 \mathrm{~m} l$ ), 再手 術例術後出血量は $868 \pm 660 \mathrm{~m} l$ (初回手術例 $655 \pm 330$ $\mathrm{m} l$ ) で, 再手術例が初回手術例比比べて術中術後とも出 血量が多い傾向を認めたが，有意ではなかった。

\section{考察}

弁膜症再手術例の予後を左右する因子として, 再手術 時の cardiac status（再手術の原因を含を）および，手 術操作に関する合併症の関与が考えられる，われわれの 死亡例 4 例中, LOS や心室性不整脈など心臟が直接死 因となった 3 例はすべて大動脈弁の paravalvular leak 症例であった。

大動脈弁疾患再手術の死亡例 3 例之生存例 4 例の再手 術前のcardiac status を比較すると死亡症例はHYMAIII ＩV度, 心不全著明, medical control 不能で, 再手術 